\title{
Marketing Florida-Friendly Landscapes to Florida Homeowners ${ }^{1}$
}

\author{
Hayk Khachatryan, Alicia Rihn, and Caroline R. Warwick²
}

Floridians are increasingly participating in do-it-yourself (DIY) activities around their houses and yards. These activities provide several benefits. Do-it-yourselfers embark on creative projects that can enhance their lives and their homes, enjoying the creative process and instilling a sense of pride in their own personal capabilities (Franke et al. 2009; Wolf and McQuitty 2013). Gardening and landscaping are two activities that are frequently performed by DIYers. Landscape projects and/or maintenance have become easier than ever before due to increased information available online, popularity of crafting/DIY-focused stores, and easy access to gardening supplies at large retailers.

Recently, consumers have become more interested in sustainable gardening and landscaping, especially if they are able to do it themselves. Florida-Friendly Landscapes (FFL) is a program unique to Florida that encourages the installation of sustainable landscapes that require fewer inputs, use less water, attract more wildlife, and are better for the environment (Florida-Friendly Landscaping 2014; Hansen et al. 2015). Florida-Friendly landscapes require little to no special equipment and can easily be completed by the everyday homeowner. Encouraging homeowners to install FFL and use FFL practices could reduce water pollution (Hansen et al. 2015). Encouraging Florida homeowners to use FFL could improve Florida's environment.

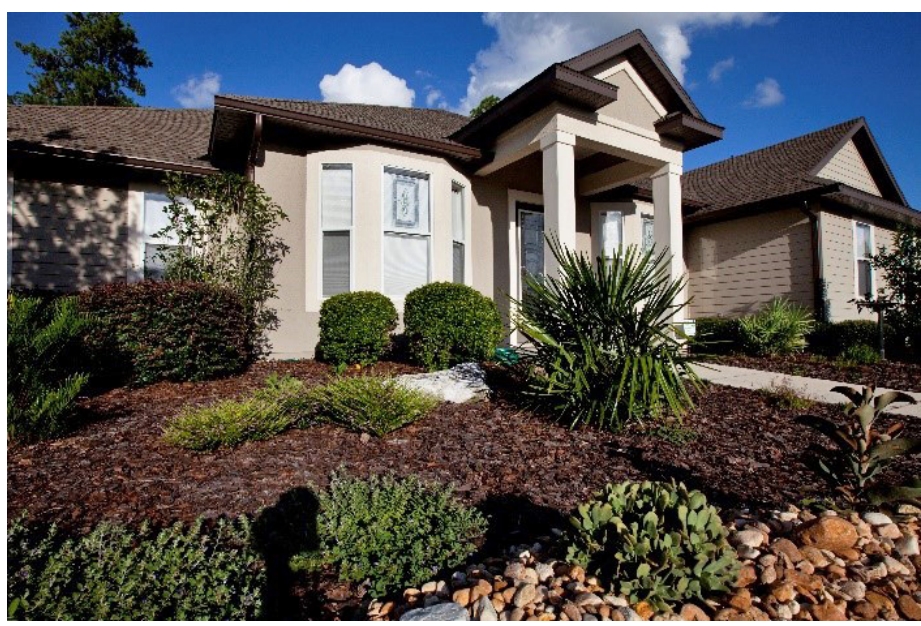

Figure 1. A Florida Friendly Yard in NW Gainesville, Florida. Credits: Tyler Jones, UF/IFAS

This publication is an overview of how both DIY and nonDIY homeowners (i.e., those who hire professional landscaping service providers) perceive the value of residential landscapes. It explores the best methods to encourage both types of homeowners to purchase or install FFL. This publication is useful to retail and landscape firms interested in encouraging FFL-related purchases and installations.

1. This document is FE1063, one of a series of the Food and Resource Economics Department, UF/IFAS Extension. Original publication date July 2019. Visit the EDIS website at https://edis.ifas.ufl.edu for the currently supported version of this publication.

2. Hayk Khachatryan, associate professor, Food and Resource Economics Department; Alicia Rihn, data management analyst; and Caroline R. Warwick, science communication specialist; UF/IFAS Mid-Florida Research and Education Center, Apopka, FL 32703

The Institute of Food and Agricultural Sciences (IFAS) is an Equal Opportunity Institution authorized to provide research, educational information and other services

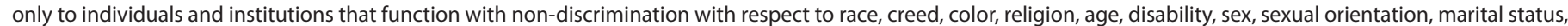

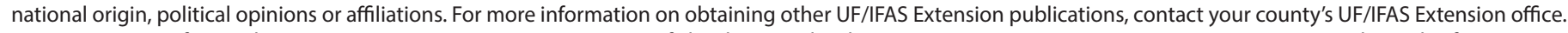
U.S. Department of Agriculture, UF/IFAS Extension Service, University of Florida, IFAS, Florida A \& M University Cooperative Extension Program, and Boards of County Commissioners Cooperating. Nick T. Place, dean for UF/IFAS Extension. 


\section{Methods}

An in-person survey was used to understand Florida homeowners' perceptions of the value of residential landscapes and the best strategies to encourage FFL. Survey questions addressed respondents' landscape care/ maintenance practices (DIY versus non-DIY), landscape value perceptions, methods to encourage FFL installation, and demographics. Pairwise t-tests were used to determine statistical differences between DIY and non-DIY groups. In pairwise t-tests, the mean difference between two groups is tested to identify if they are statistically significant from zero, meaning the observation is not likely occurring due to chance but rather due to other factors.

One hundred thirty four respondents were recruited in central Florida using newspaper advertisements, craigslist posts, printed fliers, and e-mail invitations. Of those respondents, $30.6 \%$ indicated they do their own landscape care and maintenance (hereafter termed "DIY"). On average, respondents were 52.6 years old and had obtained a 4 -year college degree at the time of the study. Household income averaged between $\$ 60,000$ and $\$ 79,999$, and the average household was 2.5 persons. The DIY group consisted of $58 \%$ women while the non-DIY group consisted of $82.5 \%$ women.

\section{Results}

An important element of residential landscapes is the benefits they provide to the homeowner. Previously, research has shown that a well-maintained landscape provides homeowners with financial benefits (Hall and Dickson 2011). These benefits can include increased property value and reduced living expenses, such as a lower electricity bill due to increased shade. This added value was combined and presented as a return-on-investment (ROI). Overall, 98\% of the sample indicated that a well-maintained landscape adds to property value. The majority of homeowners (36\%) indicated they expected an ROI between $11 \%$ and $30 \%$ for landscapes. Interestingly, non-DIY homeowners perceived less value in well-maintained landscapes, as $46 \%$ indicated the ROI would be between $11 \%$ and $30 \%$ and $30 \%$ believe the ROI would be greater than $31 \%$ (Figure 2). Conversely, $30 \%$ of DIY homeowners perceived the ROI to be between $11 \%$ and $30 \%$ while $45 \%$ of DIY homeowners viewed the ROI as being higher than $31 \%$ (Figure 2).

Respondents were also asked to indicate the best methods to encourage them to purchase and install FFLs. Respondents indicated that a greater availability of FFL plants and easier identification of FFL plants would be the most effective means of encouraging them to install FFL (Figure 3 ). They also indicated that more practical information about the benefits of FFL, tax deductions, rebates, lower installation costs, and information on the financial and environmental benefits of FFL would be effective. Less effective methods include landscape ordinances limiting irrigation water use and turfgrass areas.

Do-it-yourself homeowners were most receptive to tax deductions and rebates for installing FFL. Conversely, non-DIY homeowners were primarily influenced by information on FFL benefits, easier plant identification, and more information on the financial benefits of FFL. Landscape ordinances limiting irrigation or area devoted to turfgrass influenced non-DIY homeowners less than the other measures did, but the non-DIY homeowners were

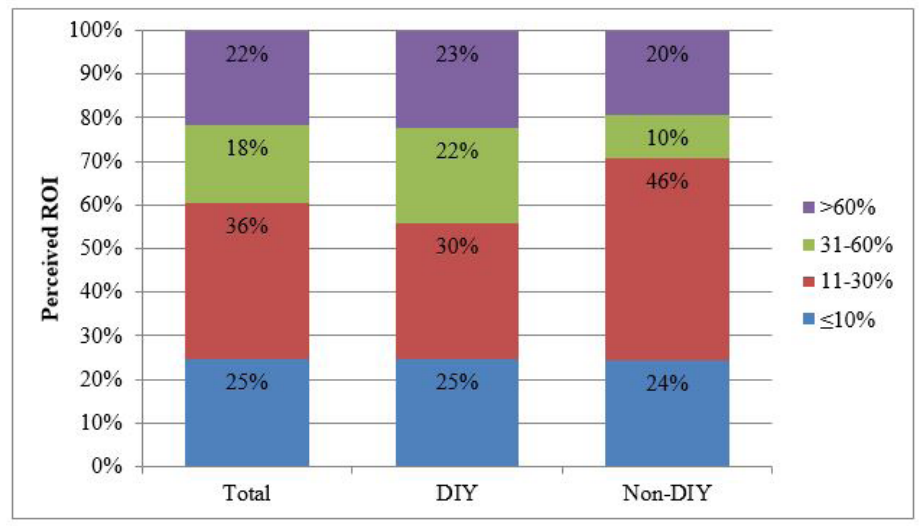

Figure 2. Participants' Perceived Return-on-Investment (ROI) for Landscapes.

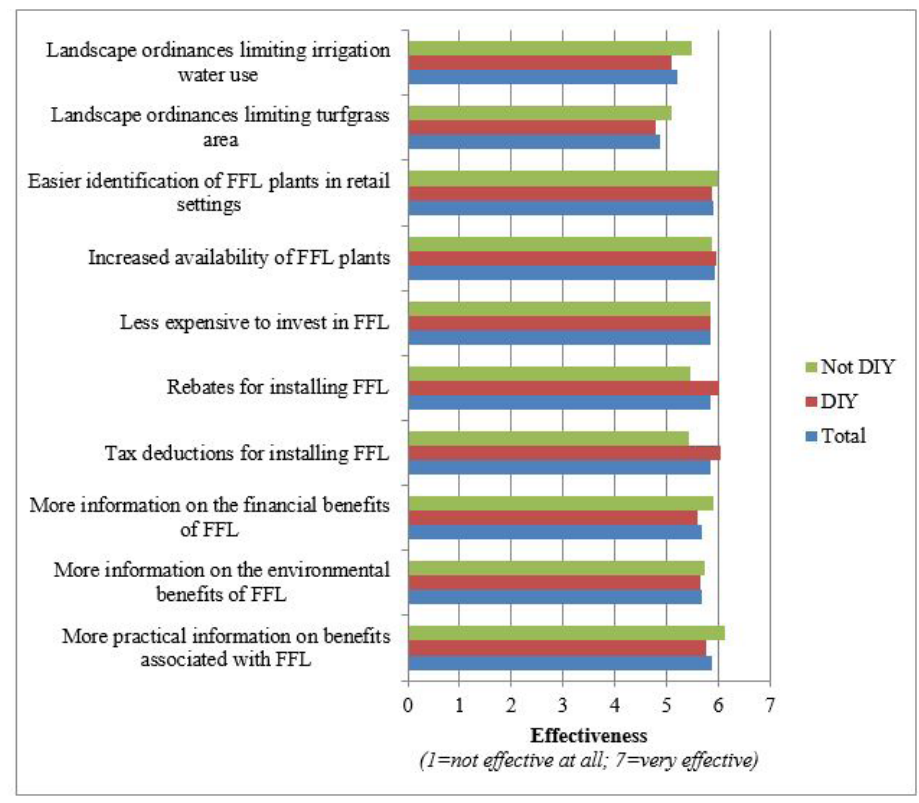

Figure 3. Effectiveness of Different Measures to Encourage FloridaFriendly Landscaping (FFL). 
more influenced by landscape ordinances than were the DIY homeowners.

\section{Summary}

Encouraging homeowners to install FFL is one means of increasing sustainability in the urban environment. However, both the benefits of encouraging homeowners to install FFL and the best means of doing so likely vary according to the homeowners' involvement with their landscapes. We assessed the differences in perceived landscape value and means of encouraging FFL between DIY and non-DIY homeowners in central Florida. Overall, both DIY and non-DIY homeowners perceive landscapes as adding to their properties' value, with DIYers having slightly higher ROI perceptions. Respondents indicated that greater product availability and information about FFL benefits were the most impactful ways to encourage them to install FLL. Additionally, DIY homeowners are more interested in financial incentives, such as rebates or tax deductions, that reduce the overall investment as a motivator for installation. Non-DIY homeowners are the most interested in benefit information and easier identification of FFL plants. Results can be used by firms to tailor their in-store/online marketing strategies to target DIY, non-DIY, or both customer groups.

The researchers have developed the following list of recommendations for retailers looking to increase sales or installations of FFL:

1. Provide customers with FFL plants, products, and landscape designs to increase availability.

2. Use point-of-sale promotions (signs, labels, etc.) and/ or website space (landscape firms) to inform customers and assist them in identifying which products or designs are Florida Friendly and the benefits associated with those products.

- If customers do not know what makes FFL products different or why they may be an improvement on other similar products, there are fewer opportunities for Florida-Friendly options to impact product choice and selection.

3. Provide customers with information about the possible benefits of FFL.
4. For firms targeting DIY customers, identify and inform customers about possible price-reducing options such as tax deductions and rebates.

5. For agencies and homeowner associations (HOAs) wanting to encourage FFL participation, provide information to homeowners about the available Florida-Friendly options and consider implementing ordinances, such as limiting irrigation and turfgrass area, to promote landscapes and landscaping practices that align with FFL principles.

\section{References}

Florida-Friendly Landscaping. 2014. Florida-Friendly Landscaping Program. Accessed June 6 2017, available online at: http://fyn.ifas.ufl.edu/

Franke, N., P. Keinz, and C. J. Steger. 2009. “Testing the value of customization: when do customers really prefer products tailored to their preferences?" Journal of Marketing 73 (5): 103-121.

Hansen, G. 2010. Landscape Elements for a Florida-Friendly Yard. ENH1163. Gainesville: University of Florida Institute of Food and Agricultural Sciences. http://edis.ifas.ufl.edu/ ep424

Hansen, G., L. Warner, P. Monaghan, T. Fogarty, C. Lewis, and E. Momol. 2015. Perceptions of Florida-Friendly Landscapes: Linking Visual Quality and Environmental Health through Landscape Codes. ENH1258. Gainesville: University of Florida Institute of Food and Agricultural Sciences. http://edis.ifas.ufl.edu/ep519

Wolf, M., and S. McQuitty. 2013. "Circumventing traditional markets: An empirical study of the marketplace motivations and outcomes of consumers' do-it-yourself behaviors." Journal of Marketing Theory and Practice 21(2): 195-210. 